\title{
Invasive Ductal Breast Cancer; Relationship with Vascular Endothelial Growth Factor and Nitric Oxide
}

\section{İnvaziv Duktal Meme Karsinomu; Vasküler Endotelyal Büyüme Faktörü ve Nitrik Oksit İlişkisi}

\author{
Hacı Kahya Özdoğan ${ }^{1}$, Fatma Ceyla Eraldemir ${ }^{1}$, Mustafa Baki Çekmen ${ }^{1}$, Çağrı Tiryaki ${ }^{3}$, İrem Yavaş ${ }^{1}$, Cengiz
} Erçin $^{2}$, Nihat Zafer Utkan ${ }^{4}$

\author{
${ }^{1}$ Kocaeli Üniversitesi Tıp Fakültesi, Biyokimya Ana Bilim Dalı, Kocaeli \\ ${ }^{2}$ Kocaeli Üniversitesi Tıp Fakültesi, Patoloji Ana Bilim Dalı, Kocaeli \\ ${ }^{3}$ Kocaeli Derince Eğitim Ve Araştırma Hastanesi, Genel Cerrahi Kliniği, Kocaeli \\ ${ }^{4}$ Kocaeli Üniversitesi Tıp Fakültesi, Genel Cerrahi Ana Bilim Dalı, Kocaeli
}

\section{ÖZET}

Amaç: Meme kanseri, kadınlarda ölüme yol açan kanserler içinde ikinci sıradadır. Kanser, meme dokusunda genellikle duktus veya lobüllerden gelişir. Bu çalışmadaki amacımız, meme karsinomunda vaskuler endotelyal büyüme faktörü (VEGF) ve nitrik oksit (NO) seviyeleri ile tümör grade'i, lenf nodu durumu ve tümör büyüklüğü işe ilişkisini araştırmaktır.

Gereç ve Yöntem: Bu çalışmada meme kanserli 50 hastada ve 38 sağlıklı kontrolde serum VEGF ve NO seviyelerini ölçtük.

Bulgular: Meme kanserli hastalarda serum VEGF ve NO seviyeleri kontrollere göre anlamlı derecede daha yüksekti $(\mathrm{p}<0.001)$. Tümör çapı açısından, meme kanserli hastalarda serum NO seviyelerinde anlamlı bir fark bulunamadı. Aksiller lenf nodu tutulum durumu açısından, meme kanserli hastalarda serum VEGF ve NO seviyelerinde anlamlı bir fark bulunamad. Meme kanserli hastalarda, serum NO düzeyleri ile serum VEGF düzeyleri arasında (r: 0.380, p=0.006) pozitif bir korelasyon vard1.

Sonuç: Serum VEGF ve NO seviyeleri meme kanserli hastalarda prognozu öngören faydalı bir belirteç olabilirler. Bu hipoteze açıklık getirmek için uzun süre takipli daha geniş çalışmalara ihtiyaç vardır.

Anahtar Kelimeler: Pankreas adenokarsinomu, gemsitabin, sisplatin

\section{ABSTRACT}

Objective: Breast cancer is the second leading cause of cancer deaths in western among woman worlwide.Cancer that forms in tissues of the breast usually the ducts or lobules. The aim of the present study was to investigate the association between serum NO and VEGF levels and lymph node status and tumor size of breast carcinoma.

Methods: In this study we measured serum VEGF and NO levels in 50 patients with breast cancer and 38 healty controls.

Results: Serum VEGF and NO levels are higher patients with breast cancer than controls $(\mathrm{p}<0.001)$. İn terms of tumoral size, there is no significant difference serum NO levels in the patients with breast cancer. There are positive correlation between serum NO levels and serum VEGF levels ( $\mathrm{r}: 0.380, \mathrm{p}=0,006)$ in the patients with breast cancer.

Conclusion: Serum VEGF and NO levels may be a useful marker to predict prognosis of patients with breast cancer.To clarify this hypothesis, larger studies with long-term follow -up are needed.

Key words: VEGF, NO, Breast cancer

\section{Giriş:}

Türkiye'deki mevcut veriler, kadınlarda görülen tüm kanser olguları içinde meme kanserinin \%77,4'lik bir oranla ilk sirada olduğunu göstermektedir. Meme kanserinin dünyada ortalama insidans1 yüz binde $38-40$ iken, Avrupa'da bu oran yüz binde 66-67, ülkemizde ise ortalama yüz binde 40 civarındadır (1).

Günümüzde meme kanserinin prognozunu belirleyen en önemli faktör aksiller lenf ganglionlarının metastaz içerip içermediği, eğer metastaz varsa tutulan 
metastatic lenf ganglionlarının sayısıdır (2). Ayrıca lenf ganglionları tümörün büyüklüğü ile ilişkilidir. Tümör çap1 arttıç̧a lenf ganglionlarının tutulum riski artmaktadır (3).

Daha önce yürütülmüş olan bazı çalışmalar, primer meme kanserli hastalarda ve erken nükslerde serum vasküler endotelyal büyüme faktörü (VEGF) seviyelerinde bir artış olduğunu rapor etmiş ve VEGF'nin tümör belirteci olarak kullanılabileceğini göstermiştir( 4,5$)$.

VEGF endotel hücreleri için özgüldür ve önemli etkileri vardır (6).Vücutta hem fizyolojik olaylarda hem de tümör büyümesi ve yayılmasını da içeren patolojik birçok hastalıkta rol oynar.( 7).

Nitrik oksit (NO) fizyolofik konsantrasyonlarda organizmanın pek çok farkl1 normal biyokimyasal süreçlerinde (vasodilatasyon, nörotransmisyon vb.) görev alan bir moleküldür. Fakat fizyolojik konsantrasyonların altındaki ve üstündeki değerleri, pek çok patofizyolojik tabloyla (tümörogenezis, anjiogenezis ve apoptozisin indüksiyonu vb.) ilişkilidirler $(8,9)$. $\mathrm{Bu}$ özelliklerinden dolay1 serum NO düzeyleri tümör patofizyolojisiyle ilişkilendirilmiştir $(10,11)$.

Çalışmamızda, meme kanseri olan hastalarda serum NO ve VEGF konsantrasyonlarını ölçüldü ve bu parametrelerin tümör boyutu ve aksiller metastazla ilişkisi araştırıldı.

\section{Gereç ve Yöntem}

Çalışma planlandıktan sonra Kocaeli Üniversitesi insan araştırmaları etik kurulundan izin alınarak çalışmaya başlandı. Araştırma için gerekli olan kan örnekleri Genel Cerrahi Servisinde yatan meme kanseri tanıs1 almış ve henüz cerrahi ve/veya medikal tedavi uygulanmamış, 36-58 yaş aralığındaki 50 kadından ve yine genel cerrahi polikliniğine başvuran, 33-53 yaş aralığında, kronik ek hastalığ1 (Hipertansiyon, Kalp Yetmezliği, Kronik vasküler hastalıklar, Diabetes Mellitus, Kronik Obstrüktif Akciğer Hastalığı, Astım vb.) bulunmayan 38 normal sağlıklı kadından alındı. Nüks meme kanseri olguları, uzak metastazı olan olgular, kronik ek hastalığı olan olgular ve çalışmaya katılmak istemeyen olgular çalışma dışı bırakıldı. Katılımcılar onam alınarak çalışmaya dahil edildi.
Meme kanseri olan ve tümör çap $5 \mathrm{~cm}$ den büyük olan 14 hastaya modifiye radikal mastektomi, tümör çap1 $5 \mathrm{~cm}$ nin altında olan ve multisentrik özellik göstermeyen 36 hastaya lumpektomi ve aksiler diseksiyon yapıldı. Hastalardan preoperatif 8 saat açlik sonrası antekübital medyan venlerinden $2 \mathrm{ml}$ kan alındı. Kan örnekleri için katkısız steril tüpler kullanıldı. Kan pıhtılaşmasını takiben $+4^{\circ} \mathrm{C}$ 'de $3500 \mathrm{rpm}$ 'de 5 dakika santrifüj edildi. Santrifüj sonras1 örneklerin süpernatant (üst) kısımlar1 2 ayrı ependorfa koyularak $-80{ }^{\circ} \mathrm{C}$ 'de sakland1. Analiz öncesi numune ependorfları çıkarılarak oda sıcaklığında çözülmeye bırakıldı ve daha sonra analizler yapıldı.Serum $\mathrm{NO}$ düzeyleri total $\mathrm{NO} 2$ düzeylerini ölçecekşekilde griess reaktifi kullanılarak spektrofotometrik olarak yapıldı. VEGF ölçümü biosource marka hazır kit kullanılarak ELISA yöntemiyle elx 800 cihazında çalışıldı (Belçika).

İstatistiksel analiz yapılırken SPSS 13.00 paket programı kullanıldı (SPSS Inc, Chicago,III,USA). Grupların normal dağılıma uygunluğu Kolmogorov Smirnov testi ile değerlendirildi. Normal dağılıma uymayan değişkenler Mann-Withney-U testiyle karşılaştırıldı. Değişkenlerin korelasyonları Spearman korelasyon verileri kullanilarak değerlendirildi. İstatistiksel anlamlılık düzeyi olarak $\mathrm{p}<0.05$ kullanıldı.

\section{Bulgular}

Çalışmaya dahil edilen hastaların demografik özellikleri Tablo 1 de özetlenmiştir. Her iki grup arasinda istatistiksel bir fark bulunmamaktadir.

Meme kanseri olan hastalar ile sağlıklı kontrollerin NO ve VEGF düzeyleri Tablo 2 de gösterilmiștir. Meme kanseri olan hastalarda serum NO ve VEGF düzeyleri kontrol grubundan anlamlı yüksek olarak tespit edilmiştir $(\mathrm{p}<0.001)$.

Tümörün çapına ve metastatik lenf nodlarına göre serum NO ve VEGF düzeyleri Tablo 3 de gösterilmiştir. Serum VEGF düzeyleri tümör çapı $\geq 5 \mathrm{~cm}$ olan meme kanserli hastalarda, tümör çapı 2-5 cm arasında olanlar ve $\leq 2 \mathrm{~cm}$ olanlara kiyasla anlaml yüksek bulunmuştur (sirasiyla $\mathrm{p}=0.001$, $\mathrm{p}=0.006$ ).

Yine ayn 1 tabloda lenf nodu metastazı durumuna göre serum NO ve VEGF 
Tablo 1. Katılımcıların demografik ve klinik özellikleri

\begin{tabular}{|c|c|c|c|}
\hline & Meme Kanserli $\quad(n=50)$ & Kontrol $(n=38)$ & p değerleri \\
\hline Yaş & $44.32(36-58)$ & $43.79(33-53)$ & $>0.05$ \\
\hline Tm çap $1 \leq 2 \mathrm{~cm}$ & $13(\% 26)$ & - & \\
\hline Tm çapı $2-5 \mathrm{~cm}$ & $23(\% 46)$ & - & \\
\hline Tm çap $1 \geq 5 \mathrm{~cm}$ & $14(\% 28)$ & - & \\
\hline \multicolumn{4}{|c|}{ Lenf nodu tutulum durumu } \\
\hline Tutulum yok & $16(\% 32)$ & - & \\
\hline 1-3 arası tutulum & $14(\% 28)$ & - & \\
\hline$\geq 4$ tutulum & $20(\% 40)$ & - & \\
\hline
\end{tabular}

Notlar; Değerler ortalama (minimum- maximum) veya n (\%) olarak verilmiştir

Tablo 2. Meme Kanseri hastalar ve sağlıklı kontrollerin NO ve VEGF düzeylerinin karşılaştırılması

\begin{tabular}{llll}
\hline & $\begin{array}{l}\text { Meme Kanseri hastaları } \\
(\mathrm{n}=50)\end{array}$ & Sağlıklı Kontrol $(\mathrm{n}=38)$ & p değerleri \\
\hline NO $(\mu \mathrm{mol} / \mathrm{L})$ & $134.830 \pm 38.362$ & $32.365 \pm 16.902$ & $<0.001$ \\
VEGF $(\mathrm{pg} / \mathrm{ml})$ & $225.054 \pm 91.004$ & $109.112 \pm 58.373$ & $<0.001$ \\
\hline
\end{tabular}

Notlar; Değerler ortalama \pm standart sapma olarak verilmiştir. NO:Nitrik oksit, VEGF: vasküler endotelyal büyüme faktörü

düzeylerinin karşılaştırılması yapılmıştır. Lenf nodu tutulumu olmayanlar, lenf nodu tutulumu say1s1 1-3 arası olanlar ve lenf nodu metastazı sayıs 4 ve daha fazla sayıda olanlar arasında NO ve VEGF düzeylerinin karşılaştırılmasında istatistiksel anlamlı bir sonuç bulunmadı.

Tablo 4, Meme kanserli hastalarda NO ve VEGF arasındaki korelasyon ilişkisini göstermektedir. Serum VEGF seviyesi ile serum NO seviyesi arasında ( $\mathrm{r}: 0.380, \mathrm{p}=0.006)$ istatistiksel olarak anlaml korelasyon saptanmıştır.

\section{Tartışma}

$\mathrm{Bu}$ sonuçlar ışığında, çalışmamıza göre, meme kanserli hastalarda serum NO düzeyi yüksektir fakat bu yükseklik tümör çapı değişiklikleri ve metastatik lenf nodu sayisindan istatistiksel olarak etkilenmemektedir diyebiliriz. $\mathrm{Bu}$ veriler, meme kanserli hastalardaki serum NO konsantrasyonu artışının primer tümörün oluşumundan itibaren kaynaklandığını düşündürmektedir.
Tümörogenezisde yüksek bulunan NO düzeyleri araştırmacılar tarafından farklı yorumlanmıştır.Cui ve arkadaşları NO'nun apopitozisi uyararak tümör büyümesini ve metastazı önleyebildiğini (13), diğer yandan ise Nathan C. ve Leiboviche artmış NO aktivitesinin, DNA hasarına yol açarak, immünspresyonu indükleyerek, vazodilatasyon ve anjiyogenez yaparak tümör büyümesini ve metastazı ilerletebileceğini yayınlamışlardır $(14,15)$.

NO ve meme kanseri arasındaki ilişkiyi tanımlamaya çalışan, fakat sonuçları değişken olan birçok çalışma vardır. Thomsen ve arkadaşları, NO biyosentezi ve nitrik oksit sentaz (NOS) aktivitesinin, meme kanseri tümör dokusunda, normal meme dokusuna ve benign meme lezyonlarına göre daha yüksek olduğunu gözlemlemişlerdir. $\mathrm{Bu}$ sonuçlar bizim sonuçlarımızla uyumludur (16). Martin ve arkadaşları da meme tümörlü hastalarda endotel kaynaklı NOS aktivitesinin bulunduğunu ve anlamlı derecede NO üretildiğini tespit etmişlerdir. $\mathrm{Bu}$ sonuçlar bizim araştırmamızla uyumludur, fakat bu 
araştırmada metastatik aksiller lenf nodu sayısı ile NO konsantrasyonu arasında, bizden farklı olarak, negatif bir korelasyon, östrojen reseptör salınımı ile NO konsantrasyonu arasında pozitif bir korelasyon olduğunu bildirmişlerdir (17).

Meme kanseri olan hastalarda yapilan çalışmalara göre, tümör dokusunda makrofaj

Tablo 3. Tümörün çapına ve Lenf nodu metastazı durumuna göre serum NO ve VEGF düzeylerinin karşılaştrılması

\begin{tabular}{|c|c|c|c|c|}
\hline & $\mathrm{NO}(\mu \mathrm{mol} / \mathrm{L})$ & $\mathrm{p}$ değerleri & VEGF (pg/ml) & p değerleri \\
\hline Tm çapi $\leq 2 \mathrm{~cm}(\mathrm{n}=13)$ & $128.62 \pm 44.83$ & 0.869 & $191.86 \pm 95.61$ & 0.479 \\
\hline Tm çap1 $2-5 \mathrm{~cm}(\mathrm{n}=23)$ & $128.72 \pm 35.18$ & & $198.01 \pm 63.36$ & \\
\hline $\begin{array}{l}\text { Tm çap } 1 \leq 2 \mathrm{~cm}(\mathrm{n}=13) \\
\text { Tm çap } 1 \geq 5 \mathrm{~cm}(\mathrm{n}=14)\end{array}$ & $128.62 \pm 44.83$ & 0.297 & $191.86 \pm 95.61$ & $0.006 *$ \\
\hline $\begin{array}{l}\text { Tm çapı } 2-5 \mathrm{~cm}(\mathrm{n}=23) \\
\text { Tm çap } 1 \geq 5 \mathrm{~cm}(\mathrm{n}=14)\end{array}$ & $\begin{array}{l}150.64 \pm 34.99 \\
128.72 \pm 35.18\end{array}$ & 0.1 & $\begin{array}{l}300.21 \pm 86.54 \\
198.01 \pm 63.36\end{array}$ & $0.001 *$ \\
\hline $\begin{array}{l}\text { Lenf nodu met yok } \\
(\mathrm{n}=16)\end{array}$ & $\begin{array}{l}150.64 \pm 34.99 \\
126.62 \pm 38.04\end{array}$ & 0.724 & $\begin{array}{l}300.21 \pm 86.54 \\
217.17 \pm 82.97\end{array}$ & 0.632 \\
\hline $\begin{array}{l}\text { Lenf nodu met } 1-3 \\
(\mathrm{n}=14)\end{array}$ & $127.00 \pm 36.55$ & & $206.45 \pm 81.60$ & \\
\hline $\begin{array}{l}\text { Lenf nodu met yok } \\
(\mathrm{n}=16)\end{array}$ & $126.62 \pm 38.04$ & 0.157 & $217.17 \pm 82.97$ & 0.664 \\
\hline $\begin{array}{l}\text { Lenf } \\
(\mathrm{n}=20)\end{array}$ & $146.87 \pm 38.53$ & & $244.38 \pm 103.27$ & \\
\hline $\begin{array}{l}\text { Lenf nodu met } 1-3 \\
(\mathrm{n}=14)\end{array}$ & $127.00 \pm 36.55$ & 0.178 & $206.45 \pm 81.60$ & 0.462 \\
\hline $\begin{array}{l}\text { Lenf nodu } \\
(\mathrm{n}=20)\end{array}$ & $146.87 \pm 38.53$ & & $244.38 \pm 103.27$ & \\
\hline
\end{tabular}

Tablo 4. Meme kanserli hastalarda NO ve VEGF arasındaki spearman korrelasyon ilişkisi

\begin{tabular}{lcc}
\hline$(\mathrm{n}=50)$ & $\mathrm{r}$ & $\mathrm{p}$ \\
\hline NO-VEGF & 0.380 & 0.006 \\
\hline
\end{tabular}

Korrelasyon, $\mathrm{p}<0.01$ seviyesinde anlamlıdır.

infiltrasyonu vardır (18).Bize göre bu hastalardaki NO artışının kaynağı ağırlıklı olarak bu makrofaj kaynaklı indüklenebilir NOS aracilığıyla üretilen NO'dur. Çünkü organizmada başta makrofajlarda olmak üzere immün sistem hücrelerinde ağırlıklı olarak bulunan indüklenebilir NOS, özellikle TNF- $\alpha$ aracılığıyla indüklenerek makrofajlarda yüksek düzeyde NO üretme kapasitesine sahiptir (19, 20).

Çalışmamızda, meme kanserli hastalarda serum VEGF seviyesini kontrol grubuna göre anlamlı derecede yüksek bulduk (Tablo 2).

Çalışmamızın bulguları ışığı altında değerlendirdiğimizde, tümör çap1 $5 \mathrm{~cm}$ 'ye ulaşıncaya kadar meme kanserli hastaların serum VEGF seviyelerindeki yükseklik belli bir düzeydedir ve tümör çap $5 \mathrm{~cm}$ 'ye ulaşınca veya geçince VEGF seviyelerindeki artış anlamlı olarak artmaktadır. Fakat metastatik aksiller lenf ganglionu sayısı, serum VEGF seviyesini istatistiksel olarak anlamlı derecede etkilememektedir.

$\mathrm{Bu}$ verilere göre, meme kanserli hastalarda serum VEGF seviyesinin arttığını; bu artışın metastatik aksiller lenf nodu sayısından bağımsız olduğunu, söyleyebiliriz.

Solid tümörün gelişimi süresince, başlangiçta, büyüyen tümörler, besinlerin tümör hücresi içine alınmasında ve metabolik atıkların hücre dışına atılmasında, difüzyon yolunu kullanabilirler. Ancak difüzyon 
mekanizmas1, lezyonun belirli bir boyutun üzerinde ( $2 \mathrm{~mm}$ ve üzeri) büyümeye devam etmesini desteklemeye yeterli olmamaktadır (21).Bu durumda avasküler tümör dokusunun progresyonu için neovaskülarite gereksinimi ortaya çıkar.Bu nedenle anijogenik aktivitenin arttırılması için VEGF ve hipoksi gibi bazı anjiogenik stimuluslar tümör dokusunun büyümesi için devreye girerler (21).

$\mathrm{Bu}$ bulgular çalışmamızdaki meme kanserli hastalarda tümör çapı $0-2 \mathrm{~cm}$ aralığında gerçekleşen serum VEGF artışının, tümör çap1 $2 \mathrm{~mm}$ ve üzeri büyüklükteyken başlayabileceğini ve tümör dokusunun çapı 2 $\mathrm{cm}$ oluncaya kadar giderek arttığını ve normalden anlamlı bir yüksekliğe ulaştı̆̆ını düşündürmektedir. Tümör çapı $2-5 \mathrm{~cm}$ arasındayken meme kanserli hastalarda serum VEGF düzeyi artışının belli bir yükseklikte kaldığını fakat $5 \mathrm{~cm}$ 'den sonra ise olasılıkla tümör vaskularitesinin daha kompleks bir hale gelmesiyle artışın iyice hızlanarak serum VEGF düzeyinin daha da yükseldiğini düşündürmektedir.

Biroccio ve arkadaşları, in vitro olarak yaptıkları çalışmada, hipoksinin VEGF artışını direkt olarak stimüle ettiğini göstermişlerdir ve ayrica meme karsinomu hücre hattında hipoksinin VEGF salınımını arttırdığını ve in vitro anjiyojenezi uyardığını yayınlamışlardır (22). Bu bulgular hipoksi-neovaskularizasyon ilişkisinin VEGF aracılı olduğunu düşündürmektedir. Bizim araştırmamızın sonuçları, tümör dokusunun hücre sayısı ve kitlesi arttıkça hücrelerin metabolizması açısından difüzyon mekanizmasının yetersizleşeceğini ve VEGF aracılı neovaskularizasyonun gelişerek tümör hücrelerinin gereksinimlerinin karşılanmaya çalışıldığını kuvvetle desteklemektedir.

Tümör çıkarıldıktan sonra serum VEGF seviyesinde anlaml bir azalma tespit eden çalışmalar, dolaşımdaki VEGF seviyesinin tümör dokusundan kaynaklanan VEGF sekresyonuna bağlı olduğu hipotezini ileri sürmüşlerdir $(5,23)$. Bu hipotezler, bizim sonuçlarımızla uyumluluk göstermektedir çünkü biz de meme kanserli hastalarda serum VEGF seviyesinin, aksiller lenf nodu metastazından bağımsız olduğunu ve tümör kitlesinin büyümesiyle paralel olduğunu gözlemledik.

Meme kanserli hastalarda serum NO seviyesi ile serum VEGF seviyesi arasinda pozitif bir korelasyonu tesbit etmemiz bize meme kanserinde anjiyogenez oluşumunda, VEGF ve NO aktivitesi arasında direkt veya indirekt bir ilişki olabileceğini düşündürmektedir.

Amb ve arkadaşları yaptıkları bir araştırmada, kanser hücrelerinde artmış NO üretiminin, VEGF seviyesini direkt arttırarak tümör anjiyogenezine katkıda bulunduğunu ve neovaskularizasyon için indüklenen VEGF'nin tümör metastaz kabiliyetini arttırdığını bildirmişlerdir (24).

Nakamura ve arkadaşları, in vivo ve in vitro olarak NO'nun VEGF ekspresyonunu indüklediğini ve nitrotirozin seviyelerinin VEGF ekspresyonunu ve lenf nodu metastaz sayıs1 ile anlamlı derecede pozitif korele olduğunu göstermişlerdir (25).

Yapılan başka bir çalışmada, VEGF'nin anjiyogenezi uyarması ve vasküler geçirgenliği arttırması için artmış NOS aktivitesinin gerekli olduğu rapor edilmiştir (26).

Sonuç olarak; Meme kanserli hastalarda serum NO seviyelerinin oluşan tümör hücrelerinin farklılaşması, tümörün büyümesi ve anjiogenez kapasitesi üzerine bir etkisi olmadığını ve prognostik bir belirteç olarak kullanılamayacağını düşünmekteyiz. Fakat meme kanseri tanısında ve en azından tedavinin takibinde bir belirteç olarak kullanılması düşünülebilir.

Meme kanserli hastalarda artmış olan serum VEGF seviyelerinin meme kanserli hastalarda klinik tanıda bir tümör belirteci olarak ve ayrıca hastalığın kliniği hakkında bilgi veren prognostik bir faktör olarak da kullanılabileceğini düşünmekteyiz. Çalışmamız genetik basamağı olmaması nedeniyle sağkalımaçısından eksiktir ve bu çalışmamızın zayıf yönüdür.eNOS gen kodu 7q35 kromozomunda lokalizedir ve 168 den fazla polimorfizm içermektedir (27).Yapılan son çalışmalarda eNOS - 786T $>\mathrm{C}$ polimofizminin prostat, mesane ve meme kanseri ile ilişkili olduğu gösterilmiştir. Yine eNOS894G $>$ T polimorfizminin meme kanseri ile ilişkisi gösterilmiştir (27).Daha fazla hasta sayılarında eNOS polimorfizmininde değerlendirildiği genetik basamağında çalışmaya eklenmesiyle çalışmanın kanıt değerinin artacağını düşünmekteyiz.

$\mathrm{Bu}$ önerileri aydınlatmak ve netleştirmek için daha ileri ve geniş kapsamlı 
araştırmalara gereksinim vardır. Tam kür sağlanmış meme kanseri hastalarının uzun dönem takipleri ve bu hastaların serum NO ile VEGF düzeylerinin takibinin bir başka çalışmanın konusunu oluşturabileceği kanaatindeyiz.

\section{Çıkar Çatışması: Yok}

\section{Kaynaklar}

1. T.C. Sağlık Bakanlığı. Türkiye Halk sağlı̆̆ Kurumu, Kanser Daire başkanlığ 1

2. Fisher B, Slack NH. Number of lymph nodes examined and the prognosis of breast carcinoma. Surg Gynecol Obstet $1970 ; 131: 79-88$

3. Mittra I, MacRae KD. A meta-analysis of reported correlations between prognostic factors breast cancer: does axillary lymph node metastasis represent biology or chronology ? Eur J Cancer 1991;27: 1574-83

4. Toi M, Hoshina S, Takayanagi T, Tominaga $\mathrm{T}$. Association of vascular endothelial growth factor expression with tumor angiogenesis and with early relapse in primary breast cancer.Jpn J Cancer Res 1994; 85:1045-9

5. Zhao J, Yan F, Ju H, Tang J, Qin J. Correlation between serum vascular endothelial growth factor and endostatin levels in patients with breast cancer. Cancer Lett 2004 ;204:87-95

6. 6-Bikfalvi A. Recent developments in the inhibition of angiogenesis : examples from studies on platelet factor -4 and the VEGF/VEGFR system. Biochem Pharmacol 2004; 68:1017-21

7. Mattei MG, Borg JP, Rosnet O, Marme D, Birnbaum D. Assignment of vascular endothelial growth factor (VEGF) and placenta growth factor (PLGF) genes to human chromosome 6p12-p21 and 14q24-q31 regions, respectively . Genomics 1996;32:168-9

8. Ohshima H, Bartsch H. Chronic infections and inflammatory processes as cancer risk factors : possible role of nitric oxide in carcinogenesis. Mutat Res 1994;305:253-64

9. Coşkun U, Ozenirler S, Sancak B, Bukan N. Serum and ascitic fluid nitrate levels in patients with cirrhosis. Clin Chim Acta 2001;306:127-32

10. Günel N, Coskun U, Sancak B, et al. Prognostic value of serum IL-18 and nitric oxide activity in breast cancer patients at operable stage. Am J Clin Oncol 2003;26:416-21.

11. Günel N, Coşkun U, Sancak B, Günel U, Hasdemir O, Bozkurt S. Clinical importance of serum interleukin -18 and nitric oxide activities in breast carcinoma patients. Cancer 2002;95:663-7

12. Bories PN and Bories C. Nitrate determination inbiological fluids by an enzimatic one-step assaywith nitrate reductase. Clin Chem 1995; 41: 904-7

13. Cui S, Reichner JS, Mateo RB, Albina JE. Activated murine macrophages induce apoptosis in tumor cells through nitric oxide-dependent or - independent mechanisms. Cancer Res 1994 ;54:2462-7
14. Nathan C. Nitric oxide as a secretory product of mammalian cells. FASEB J 1992;6:3051-64

15. Leibovich SJ, Polverini PJ, Fong TW, Harlow LA, Koch AE. Production of angiogenic activity by human monocytes requires an L-arginin/nitric oxide -synthase-dependent effector mechanism . Proc Natl Acad Sci U S A. 1994;91:4190-4

16. Thomsen LL, Miles DW, Happerfield L, Bobrow LG, Knowles RG, Moncada S. Nitric oxide synthase activity in human breast cancer. $\mathrm{Br} \mathrm{J}$ Cancer 1995;72:41-4

17. Martin JH, Alalami O, Van den Berg HW. Reduced expression of endothelial and inducible nitric oxide synthase in a human breast cancer cell line which has acquired estrogen independence .Cancer Lett 1999;144:65-74

18. Bani D, Masini E, Bello MG, Bigazzi M, Sacchi TB. Relaxin activates the L-arginine -nitric oxide pathway in human breast cancer cells. Cancer Res 1995;55:5272-5.

19. Knowles RG, Moncada S. Nitric Oxide synthases in mammals . Biochem J 1994;298:249-58.

20. Marletta MA. Nitric oxide synthase structure and mechanism. J Biol Chem 1993 ;268:12231-4.

21. Jiang C, Aqarwal R, Lü J. Anti-angiogenic potential of a cancer chemopreventive flavonoid antioxidant, silymarin: inhibition of key attributes of vascular endothelial cells and angiogenic cytokine secretion by cancer epithelial cells. Biochem Biophys Res Commun 2000;276: 371-8

22. Biroccio A, Candiloro A, Mottolese M. et al. Bcl-2 overexpression and hypoxia synergistically act to modulate vascular endothelial growth factor expression and in vivo angiogenesis in a breast carcinoma line. FASEB J 2000; 14:652-60

23. Salven P, Perhoniemi V, Tykkä H, Maenpaa, Joensuu H. Serum VEGF levels in women with a benign breast tumor or breast cancer . Breast Cancer Res Treat 1999;53:161-6

24. Ambs S, Merriam WG, Ogunfusika MO, et al. p53 and vascular endothelial growth factor regulate tumor growth of NOS2-expressing human carcinoma cells. Nat Med 1998;4:1371-6

25. Nakamura Y, Yasuoka H, Tsujimoto M, et al. Nitric oxide in breast cancer: induction of vasculer endothelial growth factor-C and correlation with metastasis and poor prognosis. Clin Cancer Res 2006;12:1201-7

26. Ku DD, Zaleski JK, Liu S, Brock TA. Vasculer endothelial growth factor induces EDRF-dependent relaxation in coronary arteries. Am $\mathrm{J}$ Physiol 1993;265: 586-92

27. Gao X, Wang J, Wang W, Wang M and Zhang J, - eNOS Genetic Polymorphisms and Cancer Risk A Meta-Analysis and a Case-Control Study of Breast Cancer Medicine 2015 ; $94: 972$ 